\title{
Changes in soil carbon stock predicted by a process-based soil carbon model (Yasso07) in the Yanhe watershed of the Loess Plateau
}

\author{
Nan Lu • Anu Akujärvi $\cdot$ Xing Wu $\cdot$ Jari Liski • \\ Zhongming Wen $\cdot$ Maria Holmberg • \\ Xiaoming Feng $\cdot$ Yuan Zeng $\cdot$ Bojie Fu
}

Received: 15 May 2014/Accepted: 24 November 2014/Published online: 9 December 2014

(C) Springer Science+Business Media Dordrecht 2014

\begin{abstract}
Contex Soil carbon sequestration is an ecosystem process that can provide important ecosystem services such as climate regulation and mitigation of global warming. Spatiotemporal variation in the soil organic carbon (SOC) stock is the basic information needed for landscape management and determination of regional carbon budgets.
\end{abstract}

Objectives The objective of this study was to evaluate the effect of ecological restoration on SOC

N. Lu $(\bowtie) \cdot X . W u \cdot X$. Feng $\cdot$ B. Fu

State Key Laboratory of Urban and Regional Ecology, Research Center for Eco-environmental Sciences (RCEES), Chinese Academy of Sciences, Beijing 100085, China

e-mail: nanlv@rcees.ac.cn

\section{A. Akujärvi · J. Liski · M. Holmberg}

Ecosystem Processes, Natural Environment Centre, Finnish Environment Institute (SYKE), P.O. Box 140, 00251 Helsinki, Finland

Z. Wen

State Key Laboratory of Soil Erosion and Dryland Farming on Loess Plateau, Northwest A\&F University, Yangling, Shaanxi, China

\section{Y. Zeng}

Key Laboratory of Digital Earth Science, Institute of Remote Sensing and Digital Earth, Chinese Academy of Sciences, Beijing 100101, China stocks and determine the influences of multiple factors in the Yanhe watershed of the Loess Plateau.

Methods We coupled the Yasso07 soil carbon model with remote sensing indices as model input. The model performance was evaluated by uncertainty and sensitivity analyses as well as validation against field measurement.

Results The modeling captured the spatial pattern of SOC variability across the landscape generally well. Net primary productivity (NPP) was the foremost factor that affecting the spatiotemporal variation of SOC density. Converting cropland to grassland was the most efficient restoration type in soil carbon sequestration in the study period. Land use change influenced the spatial correlation between NPP and SOC density by altering both litter quantity and quality. The changes in land use area tended to have higher contributions to the changes in SOC stock than did the changes in SOC density for different land use types.

Conclusions The overall effect of ecological restoration on soil carbon sequestration was dependent on the main vegetation restoration type and the time of recovery. Human-derived land use changes could have more substantial effects on soil carbon budgets compared to natural factors in a short period of time.

Keywords Soil organic carbon - Dynamic modeling $\cdot$ Carbon sequestration rate $\cdot$ Land use and land cover change $\cdot$ Uncertainty $\cdot$ Sensitivity 


\section{Introduction}

Carbon sequestration is an ecosystem process that produces several important ecosystem services such as provisioning of wood, fiber and fuel and regulation of climate. As soils store twice as much carbon as biomass, they have a great potential to regulate the concentration of greenhouse gases in the atmosphere and mitigate global warming (Lal 2004; Upadhyay et al. 2013).

Landscapes have often a high spatial heterogeneity due to the variations in topography, climate, and soil properties. Human interference further increases this heterogeneity (Pickett and Cadenasso 1995) through changes in land use such as deforestation or afforestation, and land management practices such as harvest intensity and use of fertilizers. The spatial variability in soil organic carbon (SOC) represents the interactions of multiple environmental and management factors (Mueller and Pierce 2003; Yang et al. 2007). Land use and land cover (LULC) type is, in fact, regarded as the most important factor affecting terrestrial SOC budgets (Schulp et al. 2008; Meersmans et al. 2009), as LULC change can lead simultaneously to alterations in both carbon inputs (amount and quality of litter) and losses (decomposition, leaching, and mineralization) (Conant et al. 2003; Wiesmeier et al. 2013).

Spatiotemporal variation in SOC is a prerequisite for cost-effective landscape management and decision making concerning the management of regional carbon budgets (Jastrow et al. 2005). However, detailed, spatially explicit assessments of soil carbon dynamics at landscape or regional scale are rare because of limited soil databases (Grunwald and Vasques 2010). This is due to the difficulty in carrying out time-intensive soil inventories at large spatial scales (Vagen and Winowiecki 2013). Dynamic modeling can be used for temporal predictions of SOC pools and fluxes, but most process-based soil carbon models, such as Century, RothC, CANDY, and DAISY, are complex and require very detailed input information. Therefore, carrying out SOC simulations at large spatial scales remains a great challenge (Ogle et al. 2010; Luo et al. 2013).

The Loess Plateau of China is the largest continuous area of loess in the world, characterized by low vegetation cover due to a long term history of cultivation, intensive precipitation, complex landform (i.e., hilly and gully landform), and severe soil erosion.
In the past decades, a series of large-scale restoration projects have been carried out in this region such as the Grain for Green (GfG) project initiated in 1999. The GfG project is a national program to control soil erosion by converting sloping croplands to natural vegetation. The effects of ecological restoration on the SOC stock have been investigated intensively in this region. However, most of the studies have focused on local scale (Gong et al. 2006; Chang et al. 2012; Wang et al. 2012; Xu et al. 2013). The few existing large scale studies have emphasized the comparison of SOC stock among different LULC types or its static spatial variability without considering the temporal variation (Liu et al. 2012). As a result, the assessment of temporal dynamics of SOC at landscape or regional scale is still inadequate (Feng et al. 2013; Dang et al. 2014). Therefore, it remains unclear to what extent SOC stock has changed due to LULC change, what are the main factors determining the spatial variability and change rate of SOC, and what have been the relative contributions of changes in the land use area and SOC density to the changes in SOC stock.

Coupling remote sensing indices with simple process-based ecosystem models provides an alternative for spatially explicit assessments of ecosystem services (Feng et al. 2010). An advantage of remote sensing products is the capacity to provide long time series of spatial data. In this study, we coupled the Yasso07 soil carbon model with remote sensing derived net primary productivity (NPP) and LULC classification to assess the dynamic changes of SOC density in the Yanhe watershed of the Loess Plateau. Yasso07 is a simple soil carbon model which requires only the most important input information and thus has a great potential to facilitate landscape or regional scale predictions of SOC changes (Tuomi et al. 2008, 2009, 2011a, b). It is based on a large amount of measurements of SOC density and litter decomposition and used already in various applications including earth system modeling (Thum et al. 2011) and UNFCCC greenhouse gas reporting under the Kyoto protocol in Australia, Finland, Norway, and Switzerland. Particularly, the model has been validated at multiple afforestation sites and a small catchment in the Loess Plateau (Lu et al. 2013; Wu et al. 2014), which suggested that the model would be appropriate to be applied also at larger spatial scales in this region.

The specific objectives of our study were to: (1) obtain spatially explicit estimates of SOC density in the 
Yanhe watershed; (2) examine the spatiotemporal changes in SOC density and identify the impacting factors; and (3) determine the relative contributions of changes in area and SOC density to changes in soil carbon stock for different LULC types in the landscape.

\section{Methods}

Study area

The Yanhe watershed is located in the middle area of the Loess Plateau $\left(36.35^{\circ}-37.32^{\circ} \mathrm{N}, 108.63^{\circ}-\right.$ $110.48^{\circ} \mathrm{E}$ ) with an area of $7,679 \mathrm{~km}^{2}$ (Fig. 1a). It is in the semi-arid climate zone, with the long-term mean annual precipitation (MAP) ranging from 420 to $510 \mathrm{~mm}$ across the landscape, which is within the large MAP gradient increasing from northwest to southeast in the region (Fig. 1a). Annual precipitation is concentrated in July to September. The spatial variation in the mean annual temperature (MAT) ranges from 7.5 to $10.5{ }^{\circ} \mathrm{C}$. The elevation ranges from 479 to $1,782 \mathrm{~m}$. It is a typical hilly and gully loess landscape, with multiple LULC types and varied land use history. Due to the long term soil erosion and extensive land use, the land surface is highly fragmentized (Fig. 2).

The GfG project, a national program initiated in 1999, was initially designed to retire farmland susceptible to soil erosion. The project was developed in a few pilot areas in Sichuan, Shaanxi, and Gansu provinces in 1999 and extended to 20 provinces in
2001. The Yanhe watershed has been characterized by large area of sloping farmland and the most serious soil erosion in the middle and upper reaches of the Yellow River. Therefore, it was selected as one of the pilot areas and the core region for implementing the Project in the Loess Plateau. The project was started to be fully developed in the Yanhe watershed in 2001. The main restoration types include converting cropland to forest, shrubland, and grassland.

Grassland and cropland occupied 45 and $42 \%$ of the total area, respectively, before the implementation of the project (Fig. 3). The land cover was highly fragmental, with a mixture of innumerable small patches of grassland and cropland. The land cover has experienced enormous changes after the implementation of the GfG project. The total area of cropland has reduced greatly (18\%), and grassland became the dominant LULC type in 2008 (68\% of the total area) (Figs. 2, 3). The area of cropland has decreased by $-56.9 \%$ (from 3,200 to $1,400 \mathrm{~km}^{2}$ ), and the areas of grassland, shrubland, and forest increased by 50.0, 12.9, and $5.8 \%$, respectively. The grassland patches have become larger after the vegetation restoration.

Yasso07 soil carbon model

The Yasso07 model is based on three main assumptions about litter compound groups, decomposition rate, and mass flows within and out of the system. The model input data was composed of initial SOC density, annual carbon input of litter, chemical quality of litter, MAT, MAP, and temperature amplitude (the (a)

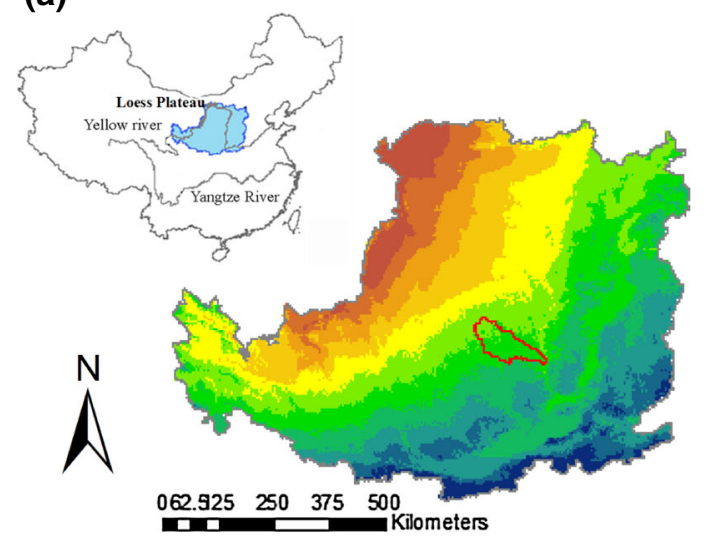

Fig. 1 a Locations of the Loess Plateau and the Yanhe watershed. The different colors represent precipitation gradient from northwest (less than $200 \mathrm{~mm}$ ) to southeast $(650-800 \mathrm{~mm})$

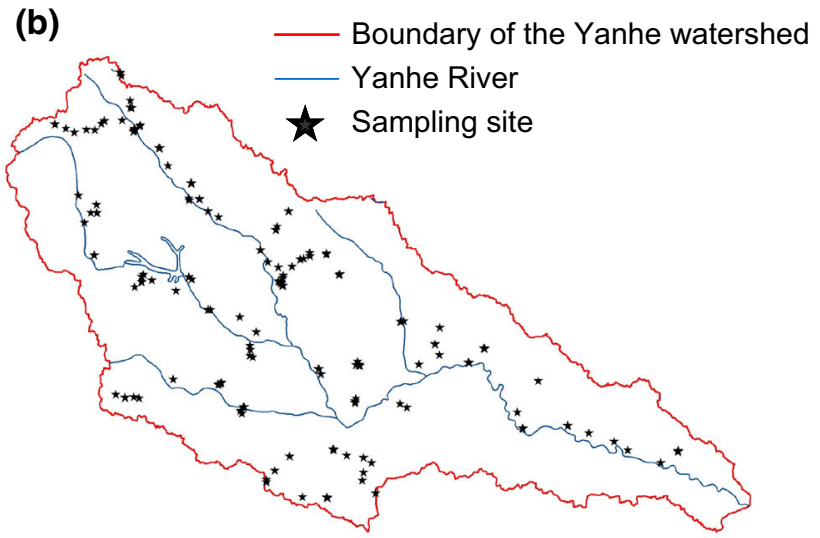

in the Loess Plateau by an interval of $50 \mathrm{~mm}$. b spatial distribution of the sampling sites for SOC measurements. (Color figure online) 
Fig. 2 Land use and land cover (LULC) maps of the Yanhe watershed in 2000 and 2008 (spatial resolution $30 \mathrm{~m})$
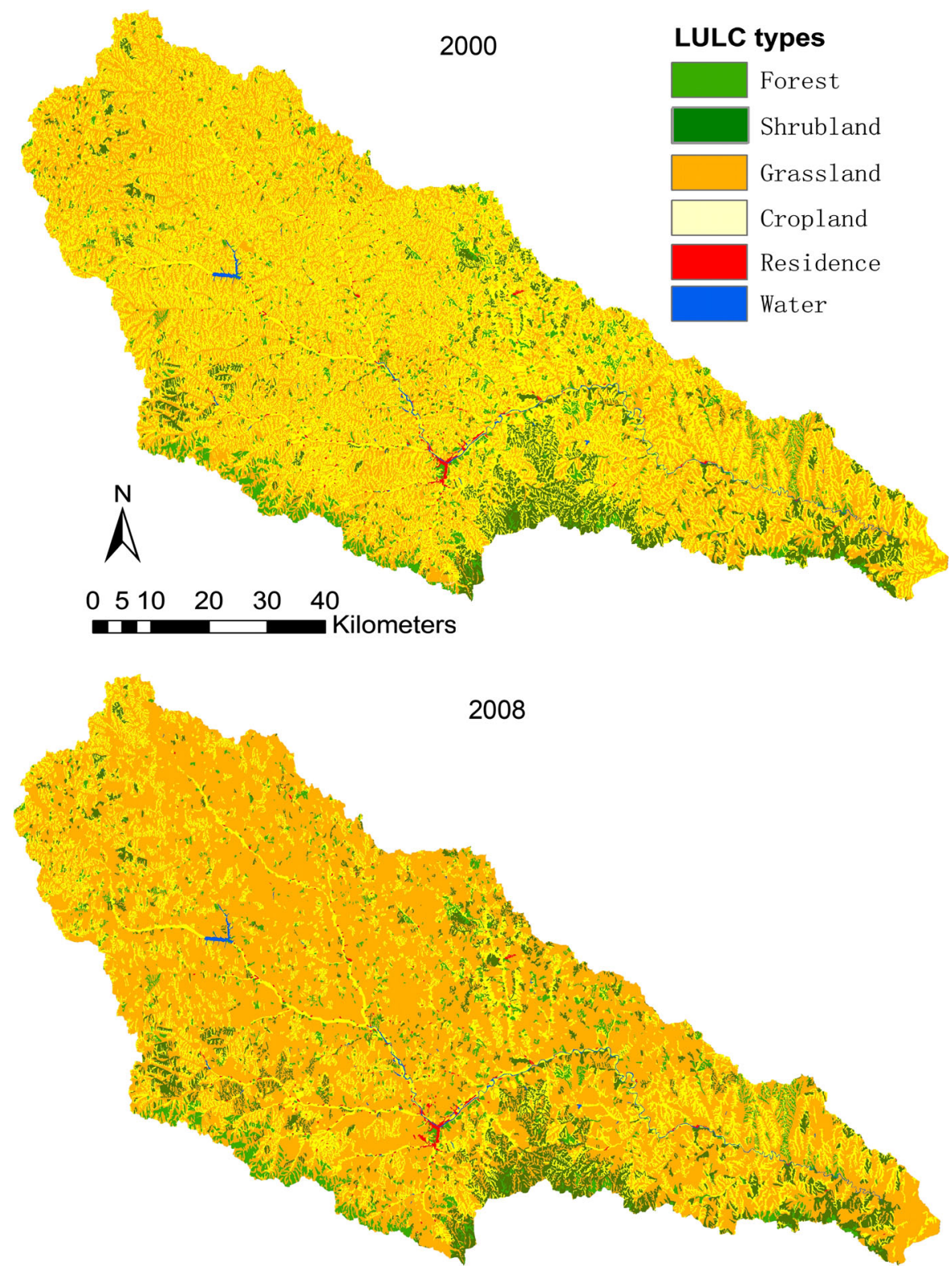

difference between the average temperatures of the warmest and coldest months). The structure and assumptions of the Yasso07 model have been described in detail in previous studies (Tuomi et al. 2009, 2011a, b; Wu et al. 2014).

Model simulations

We simulated the annual changes of SOC density of the Yanhe watershed between 2000 and 2008 by using the Yasso07 model coupled with NPP and LULC classification derived by remote sensing. The model simulates SOC density continuously across a 1 meter deep soil layer, to which the model has been parameterized based on a large dataset of measurements of SOC densities and litter decomposition worldwide.

\section{Initial SOC density and annual litter input}

When initializing the model, we used the mean values of the climatic variables in the years 1980-2000 and the NPP of 2000 to calculate the initial SOC density 
Fig. 3 The area changes among different LULC types between 2000 and 2008. a Total areas of each of the LULC types, the numbers above the bars represent percentage of change in 2008 compared to 2000, b Percentage of LULC composition in 2000 and 2008 (excluding the areas of water and residence)

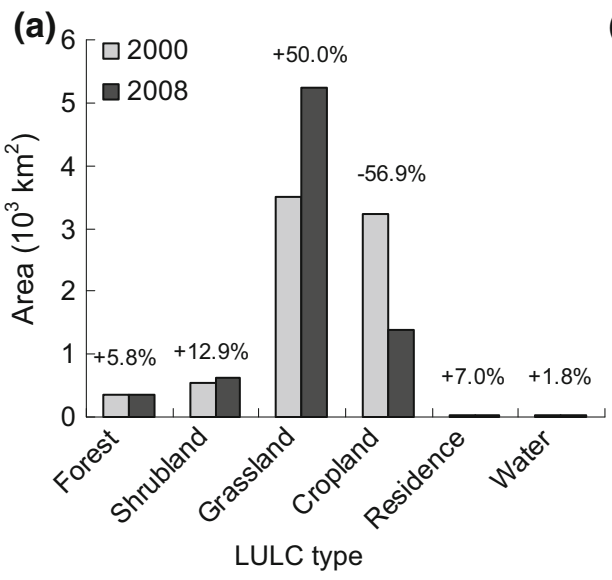

with the assumption that the SOC density was in a steady state with the carbon input from the vegetation cover (for the initialization, the number of time steps was 10,000 years). We also assumed that the annual carbon input was equal to annual NPP in the areas with consistent LULC types between 2000 and 2008. For the restoration areas (cropland converted to forest, shrubland, or grassland), the annual carbon inputs were estimated based on biomass accumulation and biomass turnover rates.

$$
\begin{aligned}
\text { Litter }_{n}= & T R_{A} \cdot \sum_{i=1}^{n} \operatorname{ANPP}_{i} \cdot\left(1-T R_{A}\right)^{n-i} \\
& +T R_{B} \cdot \sum_{i=1}^{n} \operatorname{BNPP}_{i} \cdot\left(1-T R_{B}\right)^{n-i}
\end{aligned}
$$

where $\mathrm{n}$ was the nth year from 2001 to 2008 $(\mathrm{n}=1-8)$. ANPP and BNPP were aboveground and belowground NPP, respectively. $T R_{A}$ and $T R_{B}$ were turnover rates of above and belowground biomass, respectively. As biomass usually removed during the restoration activities, the litter input was set to zero in 2001, assuming that the previous litter mass of the crops was totally removed when planting the new vegetation. The ratio of ANPP to BNPP was estimated to be 1:3 for grasses, and 4:1 for trees and shrubs (Zhang and Liang 2002, 2005; Liu et al. 2011a). The turnover rate was estimated to be 0.15 year $^{-1}$ for belowground biomass for all vegetation types, 1.0 year $^{-1}$ for grasses, and 0.10 year $^{-1}$ for shrubs and trees for the aboveground biomass. A coefficient of 0.3 was used as a harvest index for cropland.
Annual NPP was calculated for the years 2000-2008 by using the terrestrial Carnegie-Ames-Stanford Approach (CASA) model based on MODIS images (spatial resolution of $250 \mathrm{~m}$ ). The CASA model calculates light use efficiency based on solar radiation, temperature, precipitation, vegetation type, and soil type (Potter et al. 1993). It is commonly used and particularly the most efficient approach to estimate terrestrial NPP in the Loess Plateau (Feng et al. 2013). The main uncertainties of the CASA-derived NPP estimates reside on the satellite-measured vegetation indices (Wang et al. 2011b). According to the CASA model, the mean annual NPP increased from 2000 to 2008 for all of the different LULC types (Fig. 4).

\section{Litter quality}

The chemical quality of litter was estimated for nonwoody component (NWC) and woody component (WC) for each LULC type based on the species present in the study area (Adamopoulos et al. 2005; Jensen et al. 2005; Wang et al. 2011a; Shi et al. 2013a). The fraction of non-woody litter was assumed to be 1.0 in cropland and grassland, and 0.91 in forest and shrubland. The diameter of woody litter in forest and shrubland was assumed to be 2 and $3 \mathrm{~cm}$, respectively (Table 1).

\section{Climate}

The spatially extrapolated data of the annual climatic variables were obtained by using the thin-plate 


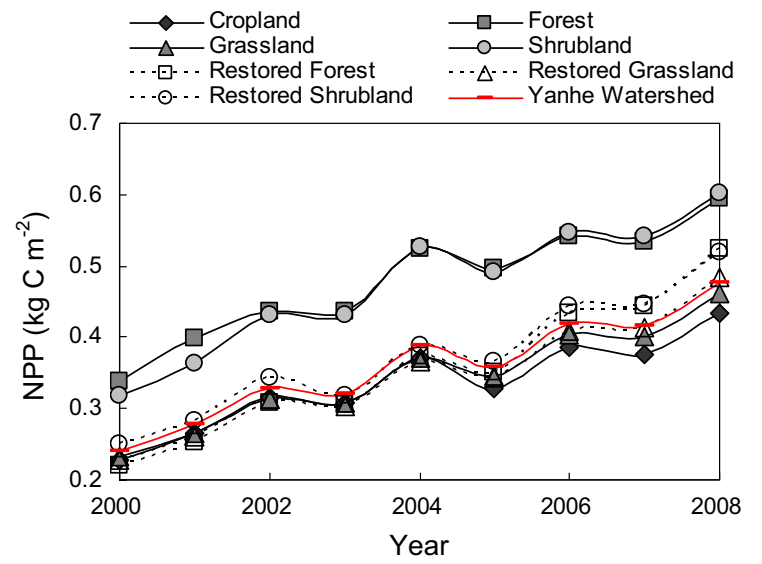

Fig. 4 Annual changes of the mean NPP in different LULC types from 2000 to 2008

smoothing spline method with ANUSPLIN 3.1 based on 172 meteorological stations in the Loess Plateau.

\section{$L U L C$}

The LULC classifications in 2000 and 2008 were derived from LandSat TM/ETM images (spatial resolution of $30 \mathrm{~m}$ ).

All of the spatial data were processed to have the same grid resolution (i.e., $250 \mathrm{~m}$ ), and the grids of all the data layers were on top of each other. It was assumed that LULC type, climate, vegetation, and NPP were uniform within each grid. The study area contained altogether 121,130 grid cells (excluding the 976 grid cells of water and residence areas).

\section{Model uncertainty}

In order to determine the uncertainty in the model parameters of the Yasso07 model in terms of probability densities, the Markov Chain Monte Carlo (MCMC) analysis was used to estimate uncertainty in the parameter values and results of the Yasso07 model (Tuomi et al. 2009). To save the calculating time for all the grid cells of the area, we analyzed the parameter uncertainty for a randomly sampled subset of 1,000 grid cells. We sampled randomly a subset of 100 parameter sets from the table of 100,000 parameter sets derived by the MCMC analysis. Then the SOC density was simulated using these 100 sets of parameter values for the subset of 1,000 grid cells representing the study area. The maximum a posteriori values and $95 \%$ confidence intervals for the parameters of the model were determined.

Beside the intrinsic parameters of the model, the model input data could also bring uncertainties to the simulations. Because the sensitivity of SOC density to the changes of climate variables has been studied thoroughly in previous studies (Sievänen et al. 2014), it was not included in this paper. We focused on evaluating the responses of SOC density to the changes in annual litter input, including the factors of NPP, ANPP: BNPP ratio and turnover rate, in the three restored LULC types. A series of scenarios were set up for these parameters. For the NPP scenarios, \pm 10 and $\pm 20 \%$ were applied. For the scenarios of ANPP: BNPP ratio, the values of $1: 4,1: 3,1: 2,1: 1,2: 1,3: 1$, and $4: 1$ were used (20-80 \% is the range of NPP allocation to aboveand below-ground for terrestrial vegetation, Lauenroth 2000). For the scenarios of turnover rates (combinations of $\mathrm{TR}_{\mathrm{A}}$ and $\mathrm{TR}_{\mathrm{B}}$ ), 0.95, 0.90, 0.85, and 0.80 were used for $\mathrm{TR}_{\mathrm{A}}$ in grassland; 0.05, 0.15, 0.20 , and 0.25 for $\mathrm{TR}_{\mathrm{A}}$ in forest and shrubland; and $0.05,0.10,0.20$, and 0.25 for $\mathrm{TR}_{\mathrm{B}}$.

Table 1 The chemical quality of litter (EWAN fractions) for non-woody component and woody component, and litter size (in diameter) for woody litter

\begin{tabular}{|c|c|c|c|c|c|c|c|c|c|c|}
\hline \multirow[t]{2}{*}{$L U L C$ type } & \multirow{2}{*}{$\begin{array}{l}\text { Fraction of } \\
\text { non-woody } \\
\text { litter }\end{array}$} & \multicolumn{4}{|c|}{ Non-woody litter $(N W C)$} & \multicolumn{4}{|c|}{ Woody litter $(W C)$} & \multirow[t]{2}{*}{ Diameter $(\mathrm{cm})$} \\
\hline & & $E$ & $W$ & $A$ & $N$ & $E$ & $W$ & $A$ & $N$ & \\
\hline Forest & 0.91 & 0.082 & 0.259 & 0.409 & 0.250 & 0.023 & 0.016 & 0.648 & 0.313 & 3 \\
\hline Shrubland & 0.91 & 0.090 & 0.170 & 0.450 & 0.290 & 0.012 & 0.081 & 0.719 & 0.188 & 2 \\
\hline Grassland & 1 & 0.356 & 0.185 & 0.394 & 0.065 & 0 & 0 & 0 & 0 & 0 \\
\hline Cropland & 1 & 0.200 & 0.250 & 0.490 & 0.060 & 0 & 0 & 0 & 0 & 0 \\
\hline
\end{tabular}

$E$ soluble in a non-polar solvent, such as ethanol or dichloromethane, $W$ soluble in water, $A$ hydrolysable in acid, $N$ neither soluble nor hydrolysable 
Model validation

To evaluate the model performance, we compared the simulated values of SOC density to measurements (Yang 2010; Shi et al. 2013a). A total of 177 soil samples were taken across the study area in JulyAugust of 2008 (Fig. 1b) and the SOC density in 0-20 cm of soil depth was measured. The sampling sites covered all LULC types of the study area, including 30, 37, 71, and 39 sites for cropland, forest, grassland, and shrubland, respectively. Detailed sampling design and experiment were described in Shi et al. (2013a). It is suggested that SOC densities in $0-20 \mathrm{~cm}$ and $0-100 \mathrm{~cm}$ of soil are correlated linearly, with the latter approximately 3 to 5 times of the former (Jobbágy and Jackson 2000; Zhang et al. 2013; Deng et al. 2014). Therefore, the measurements from 0-20 cm soil depth could be used to evaluate the modeling results. It is, however, noteworthy that the soil samples taken from the vegetation plots may be biased when compared to the grid simulations due to mismatch of their scales.

Data analyses

In order to separate the relative contribution of changes in land use area $\left(\mathrm{km}^{2}\right)$ and SOC density $\left(\mathrm{kg} \mathrm{m}^{-2}\right)$ to the changes in SOC stock (Tg mass, i.e., $10^{12} \mathrm{~g}$ ) in the entire landscape (including both unchanged areas and restored areas) in the given period of time, the relative rate of change in area (A, $\% / y e a r)$ and the relative rate of change in SOC density (S, \%/year) were calculated.

Relative contribution of change in area $(\%)$

$$
=\mathrm{A} /(\mathrm{A}+\mathrm{S}) \times 100 \%
$$

Relative contribution of change in SOC (\%)

$$
=\mathrm{S} /(\mathrm{A}+\mathrm{S}) \times 100 \%
$$

This method was proposed by Fang et al. (2014), who used it to separate the relative contributions of forest expansion and forest growth to forest biomass carbon sinks. We conducted this analysis for the four LULC types, i.e., cropland, forest, shrubland, and grassland, noting that forest, shrubland, and grassland included both the unchanged and the restored areas.

\section{Results}

Model performance

The simulated SOC density showed large spatial variation across the landscape (Fig. 5), ranging from 1.1 to $20.1 \mathrm{~kg} \mathrm{C} \mathrm{m}^{-2}$ (mean of 2000-2008). By comparing the field measurements and the simulated values across the study area, we found that the simulated density of SOC was significantly correlated with the observed values $\left(\mathrm{R}^{2}=0.41, \mathrm{p}<0.001\right)$ (Fig. 6), indicating that the simulations captured the spatial pattern of the SOC density across the landscape. The result also showed that the mean SOC density was about 4.5 times of that in the $0-20 \mathrm{~cm}$ depth, which was within the reasonable range based on previous studies.

The uncertainty analysis indicated that the uncertainty in parameter values was on average $12.5 \%$ (deviation from the mean value) (Fig. 7). The analysis based on the subset of sites (1,000 sampled sites) did not have virtual influence on the uncertainty estimate as the mean SOC density of all sites fell in the range of the $95 \%$ confidence intervals of the 1,000 sites (figure not shown).

The sensitivity analysis provided us with more information on the magnitude of uncertainties from the model input data. The results showed that the change of the SOC density was in the similar fraction to that of NPP (Fig. 8a-c). This indicated that the SOC density was very sensitive to NPP variation. The responses of the SOC density to the change of ANPP:BNPP ratio and turnover rate were dependent on the LULC type. The SOC density was more sensitive to the changes of $\mathrm{TR}_{\mathrm{B}}$ than $\mathrm{TR}_{\mathrm{A}}$ in grassland whereas in forest or shrubland it was more sensitive to the changes of $\mathrm{TR}_{\mathrm{A}}$ than $\mathrm{TR}_{\mathrm{B}}$ (Fig. 8d-f). Similarly, the SOC density was more sensitive to decreased than increased BNPP:ANPP ratio in grassland but it was more sensitive to increased than decreased BNPP:ANPP ratio in forest or shrubland (Fig. 8g-i). In addition, the changed ANPP:BNPP ratio and turnover rates affected the rate of change in SOC given the NPP level.

Spatial distribution of SOC density

The spatial distribution of the SOC density was highly dependent on that of the LULC classification (Figs. 2, 5). The mean SOC density $\left(\mathrm{kg} \mathrm{C} \mathrm{m}^{-2}\right)$ in the 
Fig. 5 Distribution of simulated SOC density $\left(\mathrm{kg} \mathrm{C} \mathrm{m}^{-2}\right)$ in the $0-100 \mathrm{~cm}$ of soil in the Yanhe Watershed in 2000 and 2008. The images were created in ArcGIS based on the output of the spatially explicit version of the Yasso07 model (spatial resolution $250 \mathrm{~m}$ ). The areas covered by residence and water did not have SOC values (shown as white in the maps). (Color figure online)
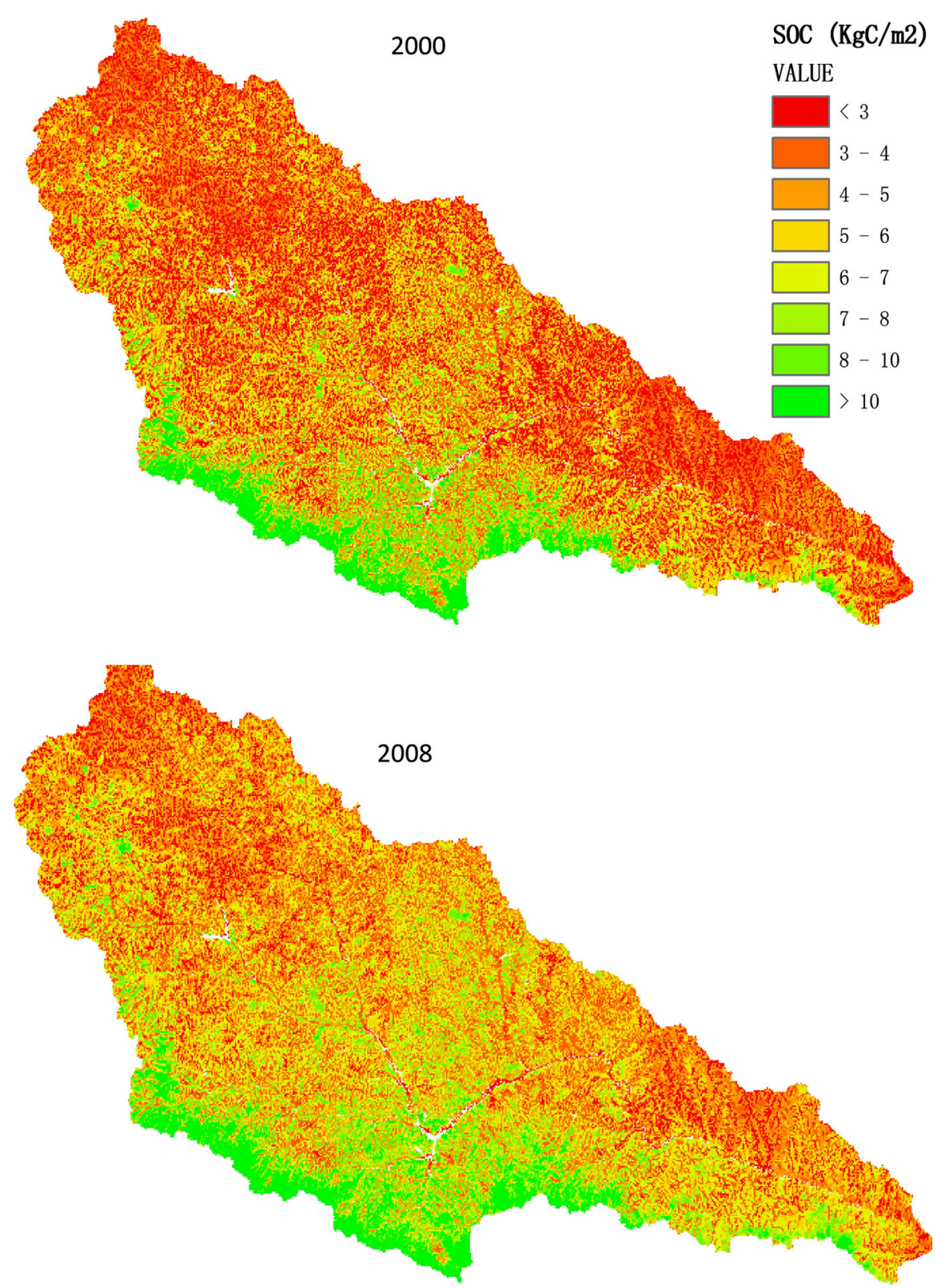

unchanged areas with consistent LULC types during the simulation period was 8.0 in the forest, 7.7 in the shrubland, 6.0 in the grassland (regarded as natural vegetation), and it was 3.2 in the cropland. For the restoration areas, it was 3.3,3.1, and 2.8 in the restored shrubland, restored grassland, and restored forest, respectively.

NPP accounted for up to 71.4-93.1\% spatial variation of SOC density in different LULC types. For the entire landscape, however, NPP alone only explained 43.1-74.1\% of spatial variation in SOC density. This suggested that LULC type played an important role in altering the spatial correlations between NPP and SOC. Nevertheless, NPP was the key determinant of SOC, and it was necessary to analyze the impacting factors of the spatial variability in NPP. The multivariate regression analysis showed that the spatial variability in NPP was mainly explained by MAP and MAT (22.7-47.0\%), with LULC type explained additional 3.5-6.9\%. 


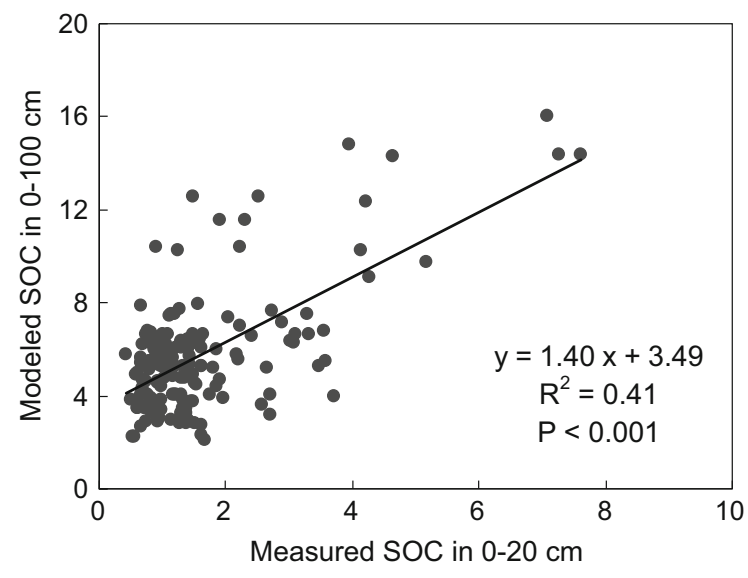

Fig. 6 Correlations between the modeled and the measured SOC density $\left(\mathrm{kg} \mathrm{C} \mathrm{m}^{-2}\right)$

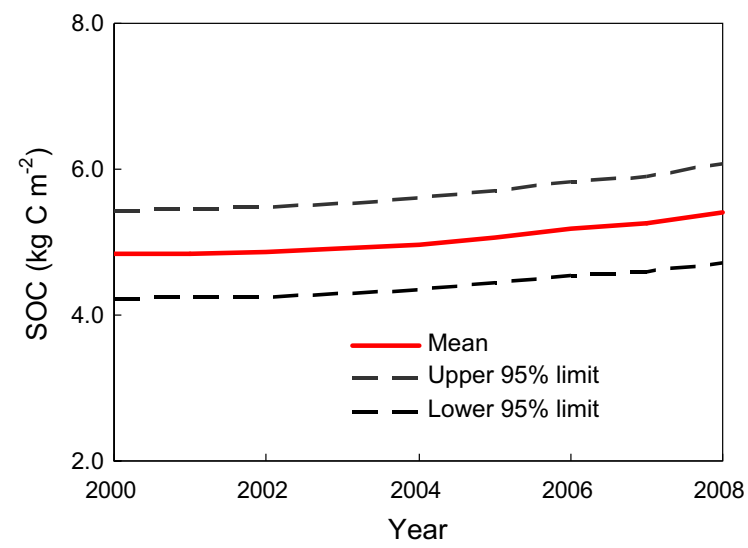

Fig. 7 Uncertainty analysis of the Yasso07 model parameters using the distribution of parameter values derived by the MCMC analysis. Mean simulated SOC stocks densities and upper and lower $95 \%$ confidence intervals

Landform factors had little effects on the spatial distribution of NPP (Table 2).

Temporal changes in SOC density

The mean SOC density in the landscape increased from 4.8 to $5.4 \mathrm{~kg} \mathrm{C} \mathrm{m}^{-2}$ between 2000 and 2008 . The overall change rate was $72.1 \mathrm{~g} \mathrm{C} \mathrm{m}^{-2}$ year $^{-1}$. The temporal changes in SOC density were distinct among the LULC change types (Fig. 9). In the areas of unchanged LULC types from 2000 to 2008, the mean SOC density increased continuously with time. The change rate in the SOC density was 47.5, 84.2, 95.5, and $113.3 \mathrm{~g} \mathrm{C} \mathrm{m}^{-2}$ year $^{-1}$ in the cropland, grassland, forest, and shrubland, respectively. In the restored forest and shrubland, however, the SOC density decreased in the first 3-4 years after restoration and then recovered slowly until the year 2008. In the restored grassland, the SOC density showed a slight decrease in the first few years, recovered to the original level quickly and continued to increase thereafter with the rate of $47.8 \mathrm{~g} \mathrm{C} \mathrm{m}^{-2}$ year $^{-1}$.

Change in SOC stock in the landscape

The total soil carbon stock in the landscape increased from 36.7 to $40.8 \mathrm{Tg}$ from 2000 to 2008 . The change in the SOC stock in the landscape is the outcome of changes both in the areas and the SOC densities of different LULC types. When considering the unchanged and the restored areas as a whole for each LULC type, the relative change in the area was 0.6 , $1.5,5.1$, and $-6.4 \% / y e a r$, and the relative change in the SOC density $0.7,0.6,-0.5$, and $1.4 \%$ year for forest, shrubland, grassland, and cropland, respectively. Consequently, the relative changes in total SOC stock in the four LULC types were 1.3, 2.1, 4.6, and $5.0 \% /$ year, respectively (Fig. 10a).

The contribution of the area change (47.7-128.5\%) was larger than that of the SOC density ( $-9.3-52.3 \%)$ during the study period for the four LULC types (Fig. 10b). The contribution of the area change was especially high for cropland and grassland because large areas of cropland were converted to grassland. The total SOC stock in the cropland decreased because the effect of the decrease in the area over-compensated the increase in the mean SOC density. Conversely, the total SOC stock in the grassland increased because the effect of area expansion due to newly restored grassland over-compensated the decrease in the mean SOC density in the grassland.

\section{Discussion}

SOC density in different LULC types

LULC is a direct factor driving the changes in soil carbon density as it leads to the changes in biomass productivity, vegetation type, soil conditions, soil microbes and mesofauna. In our study, LULC type itself accounted for $32.9-36.0 \%$ of spatial variation in 


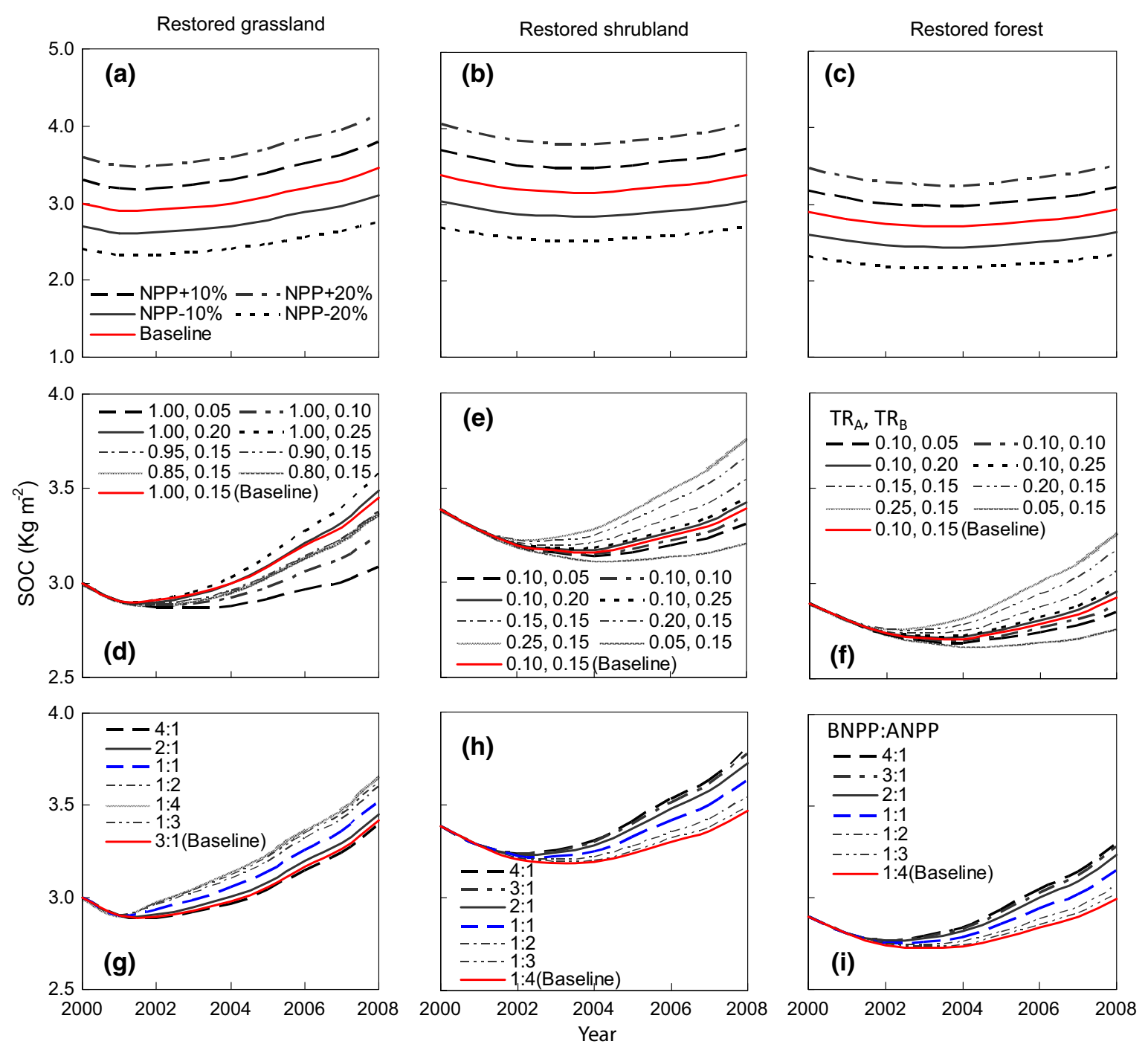

Fig. 8 Sensitivity of SOC responses to the changes of NPP $(\mathbf{a}, \mathbf{b}, \mathbf{c})$, turnover rate $\left(\mathrm{TR}_{\mathrm{A}}\right.$ for $\mathrm{ANPP}$ and $\mathrm{TR}_{\mathrm{B}}$ for $\left.\mathrm{BNPP}\right)(\mathbf{d}, \mathbf{e}, \mathbf{f})$, and BNPP:ANPP ratio $(\mathbf{g}, \mathbf{h}, \mathbf{i})$ in the three restoration types

SOC density. Previous studies indicate that the SOC density is the largest in forest $\left(9.4-11.4 \mathrm{~kg} \mathrm{C} \mathrm{m}^{-2}\right)$ and second largest in shrubland $\left(7.2-8.8 \mathrm{~kg} \mathrm{C} \mathrm{m}^{-2}\right.$ ) and grassland $\left(5.9-7.1 \mathrm{~kg} \mathrm{C} \mathrm{m}^{-2}\right.$ ) in $0-100 \mathrm{~cm}^{-2 o i l}$ depth in the Ziwuling forest region, a well-protected area of natural vegetation in the Loess Plateau (Zhao et al. 2006; Yang et al. 2010; Li et al. 2011). In another study, the mean SOC density was about $4.9-5.1 \mathrm{~kg}$ $\mathrm{C} \mathrm{m}^{-2}$ across the forest-grass zone and typical grassland zone in the Loess Plateau (Liu et al. 2010). Our simulation results of SOC density were generally in the same range and in the same order compared to the empirical studies. The SOC density in the newly restored areas was obviously lower than that in the areas with natural vegetation. Cheng et al. (2011) reported that the mean SOC density was 2.2-3.4 $\mathrm{kg} \mathrm{C} \mathrm{m}^{-2}$ in the beginning of grassland restoration and it increased to 3.6-5.5 after 11 years recovery in the typical grassland zone of the Loess Plateau. Without separating restored and natural vegetation, the mean SOC density in $0-100 \mathrm{~cm}$ soil depth was about $6.5 \mathrm{~kg} \mathrm{C} \mathrm{m}^{-2}$ in the grassland and 
Table 2 Multivariate regression analysis on the spatial variability in NPP across the landscape

\begin{tabular}{lc}
\hline Predictors included & $\begin{array}{l}\text { Variance } \\
\text { explained (\%) }\end{array}$ \\
\hline LULC & $6.4-8.8$ \\
MAT, MAP & $22.7-47.0$ \\
MAT, MAP, LULC & $27.4-51.2$ \\
MAT, MAP, LULC, ELE, SLP, ASP & $29.3-52.6$ \\
\hline
\end{tabular}

The analyses were conducted for different years from 2000 to 2008 separately. Parameters are significant at $p$ values $<0.05$

The predictors include LULC type, MAT, MAP, ELE elevation, $S L P$ slope degree, ASP slope aspect

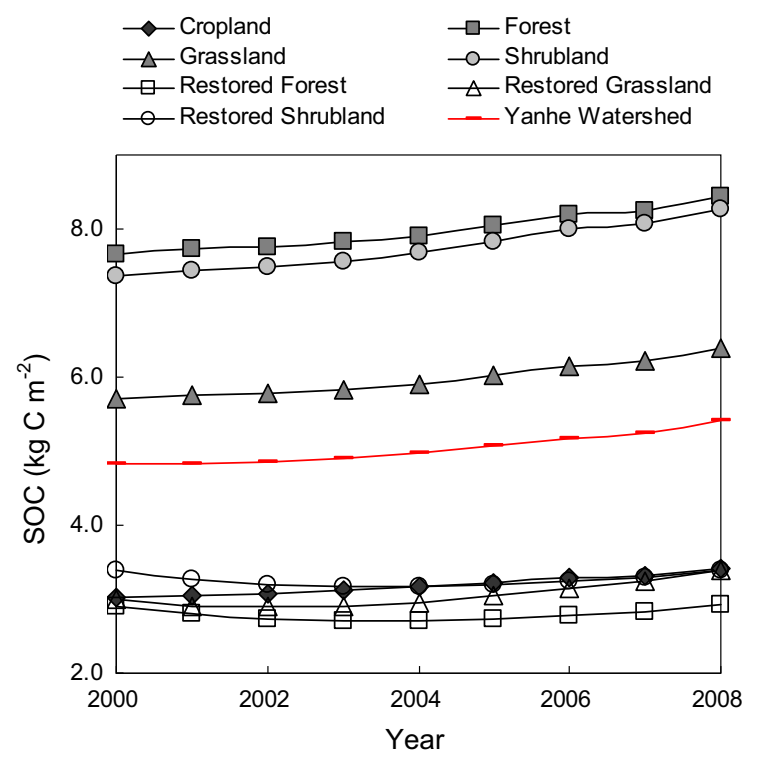

Fig. 9 Annual changes of the mean SOC density in different LULC types from 2000 to 2008 . The SOC density in 2000 represented the initial SOC state before implementation of the GfG project

$7.3 \mathrm{~kg} \mathrm{C} \mathrm{m}^{-2}$ in the forest across the Loess Plateau (Liu et al. 2011b). In addition to the model validation based on the measurements of spatial sampling (Fig. 6), the previous studies also proved that our simulation results could represent the mean SOC levels of different LULC types.

\section{Spatial variation in SOC density}

The simulations produced the basic spatial differences of SOC density across the space as comparing to the observed data, which indicated that litter input derived
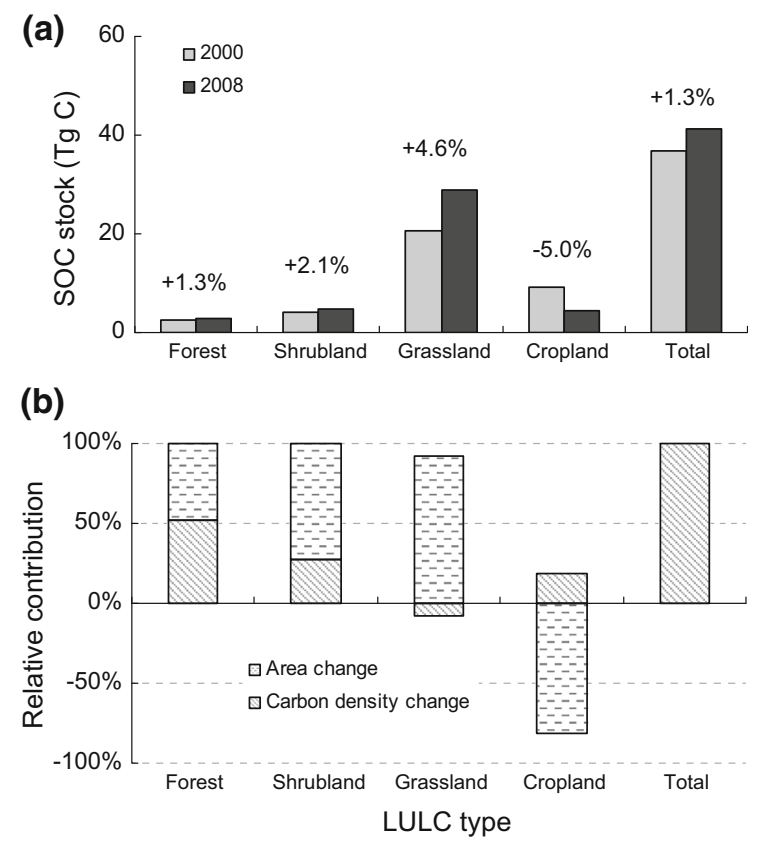

Fig. 10 a Comparison of the SOC stocks $(\operatorname{Tg} \mathrm{C})$ in the Yanhe watershed in 2000 and 2008, the numbers above the bars represent the relative change in the SOC stock between the two years. $\mathbf{b}$ The relative contribution of change in area and SOC density to the change of SOC stock in each LULC type and the entire landscape. Note that each LULC type represents both the unchanged and the newly restored areas

from NPP and climatic factors were the major causes for the spatial variability of SOC density. It is usually regarded that NPP and SOC changes have a coupling relationship, although some empirical and theoretical evidences showed that changed soil inputs may have little effects on SOC (Todd-Brown et al. 2014). Climate is the common factor that affects NPP and SOC density simultaneously. At global scale, the spatial pattern of leaf litter decomposition is similar to that of NPP because both processes are controlled by the combined conditions of temperature and precipitation (Tuomi et al. 2009). Our study suggested that NPP was the key determinant of SOC. MAP and MAT explained 22.7-47.0\% spatial variation in NPP with LULC explaining a small proportion. However, SOC was more dependent on LULC type. LULC change was an important factor that weakened the coupling relationship between the changes in NPP and SOC density by altering the amount of litter input and litter quality as well as decomposition rate under given climate conditions (Poeplau and Don 2013; Shi et al. 2013b). Slope degree and aspect did not significantly 
affect NPP or SOC density, which were consistent with some other studies (Wang et al. 2002; Mueller and Pierce 2003).

\section{Temporal changes of SOC in different LULC types}

Any factors and processes that affect litter input and soil carbon decomposition will influence the direction and rate of change in SOC density (Post and Kwon 2000). The continuous increase of SOC density in the unchanged LULC types in our study indicated that the accumulation of SOC was mainly driven by the increased NPP (Fig. 4) as both temperature and precipitation did not show significant trends of increase in the study period (data not shown). The increasing trends of NPP could be mainly due to the changed solar radiation, elevated $\mathrm{CO}_{2}$ concentration in the atmosphere, and $\mathrm{N}$ deposition as being found globally (Piao et al. 2006). The higher change rates of SOC density in the unchanged forest, shrubland, and grassland than the cropland may be mainly due to biomass harvest in croplands.

Conversion from cropland to grassland had the highest efficiency to increase SOC density with compared to the other two restoration types, which was consistent with previous findings (Falloon et al. 2006; Poeplau et al. 2011). The SOC density in the restored LULC types decreased during the first 3-4 years mainly because the decrease of litter input to the soil after removing the remnant biomass of crops and acceleration of SOC decomposition by soil disturbances in land preparation (Jandl et al. 2007). In the restored grassland, however, the recovery of litter input was faster due to the higher turnover rate of grass biomass (by litter returning from the dead roots to the soils especially for annual herbs). According to a synthesis study of the effect of vegetation restoration on SOC density at national scale (Deng et al. 2014), grassland was the most efficient restoration type in the period of 6-30 years after restoration. Forest restoration usually became as efficient as grassland restoration only after a $\sim 10$-year time lag.

\section{Carbon sequestration in the landscape}

The mean rate of increase in SOC density in $0-100 \mathrm{~cm}$ of soil was $67.2 \mathrm{~g} \mathrm{C} \mathrm{m}^{-2}$ year $^{-1}$ in the areas of vegetation restoration in the Yanhe watershed. The rate was comparable to the estimates obtained from the entire GfG project implementation area in China, which was $36.7 \mathrm{~g} \mathrm{C} \mathrm{m}^{-2}$ year $^{-1}$ in $0-20 \mathrm{~cm}$ of soil $(67.2 / 36.7=1.8$ times $)$ in Zhang et al.'s (2010) study, and $75.0 \mathrm{~g} \mathrm{C} \mathrm{m}^{-2}$ year $^{-1}$ in $0-100 \mathrm{~cm}$ in Deng et al.'s (2014) study. In the Yanhe watershed, $95 \%$ of the restored area was by grassland restoration converted from cropland. In contrast, for all of China, only $6.6 \%$ of restored vegetation was grass, and the other $93.4 \%$ was forest or shrub (Song et al. 2014). Therefore, the similar or relatively higher rate of SOC increase in the Yanhe watershed compared to the national mean was probably due to the fact that the assessment was conducted for a short restoration time ( 8 years) and grassland restoration was the dominant restoration type in this landscape. In the long term, the increasing rate of SOC density in the Yanhe watershed could be lower than the national mean because the efficiency of SOC sequestration in different vegetation types would change over time. Similarly, the higher change rate of SOC density in our study compared to that of a small catchment ( $39.8 \mathrm{~g} \mathrm{C} \mathrm{m}^{-2}$ year $\left.^{-1}\right)$ may be because plantation was the main restoration type in that area (Wu et al. 2014). Therefore, we claim that the mean change rate of SOC density in a given area depends on the main restoration type and the period of time since land conversion.

For the entire landscape, the change of soil carbon stock resulted from the changes in both the land use area and the SOC density. In our study, the change in the area tended to contribute a larger fraction to the change in soil carbon stock than did the change in the SOC density for each LULC type. This was due to the fact that the effect of LULC change on SOC density usually emerged after a long period of time (Schulp and Verburg 2009), while the change of area in the LULC type could occur instantly at large spatial scales, as happened in the Yanhe watershed during the implementation of the GfG project. It is noteworthy that the change in the SOC density is the outcome of changes in site development following restoration, ecosystem productivity, and climatic variations. Similarly, Fang et al. (2014) found that the expansion of forest area in China led to a higher contribution (60\%) to biomass carbon sinks than that of forest growth (40\%) during the 1970s-2000s. These findings indicate that LULC change due to human activities rather than natural factors could have more substantial effects on landscape or regional carbon budgets in a short period of time. 
Sources of uncertainty

Uncertainties of the simulations can be attributed to several sources, including model parameterization, initialization of SOC stock, and model input data (Figs. 7, 8). In our study, the estimation of initial SOC stock in each grid cell was based on NPP input in 2000, the LULC classification in 2000, and average climate conditions between 1980 and 1999. The climate, NPP, and LULC changes in the past may contribute to uncertainties in the estimate of the initial SOC stock in this study. In addition, it was assumed that the restoration started at the same time (i.e., 2001) for all the restored areas but in fact some specific areas started vegetation restoration earlier or later. This may lead to under- or over-estimation of the simulated SOC density at the grid scale. Restoration activity may not lead to loss of all the previous litter biomass, especially for the case of cropland abandoned to allow natural restoration. The assumption of zero litter input in 2001 could result in another source of uncertainty for simulating SOC density in the restored LULC types. Moreover, the use of the mean values of EWAN, ANPP: BNPP ratio, ratio of non-woody to woody litter mass across the landscape also contributed some uncertainties as these values could have high spatial variability.

Future challenges

Three main challenges exist in acquiring more accurate estimation of SOC stocks and better understanding of its spatiotemporal changes. Firstly, repeated field measurements of SOC density are needed for determination of the actual initial state of the SOC stock and model validation in different years. Secondly, this study assumed that LULC type, climate, vegetation, and NPP were uniform within each grid. However, land conversion usually occurred in smaller areas compared to the spatial resolution of the grid $(250 \mathrm{~m} \times 250 \mathrm{~m})$. Using remote sensing data of finer spatial resolution will be helpful to get more accurate estimate of litter mass (Hashimoto et al. 2011) and LULC classification, but this would lead to longer computing time. The advantages and disadvantages need to be weighed. Lastly, the effect of soil erosion processes on the redistribution of SOC should be considered in this area (Yadav and Malanson 2008).
Integration of the process-based soil carbon model and soil erosion model is necessary in further studies.

\section{Conclusions}

This study investigated the dynamics of SOC density in a $0-100 \mathrm{~cm}$ soil depth in the Yanhe watershed from 2000 to 2008 by coupling a process-based soil carbon model with remote sensing-derived annual carbon input and LULC classification data. The modeling approach performed generally well in simulating the spatial and temporal changes in SOC density in the study area.

The SOC density increased greatly due to the GfG project, and converting cropland to grassland was the most efficient in enhancing soil carbon density compared to other restoration types in the study period. NPP was the foremost factor affecting the spatial and temporal changes in SOC density. The study results corroborated that over a short period of time, humanderived LULC changes could have more substantial effects on landscape or regional soil carbon budgets than those of natural factors, such as vegetation development, plant growth, and interactions with climate, which may be prominent over the long term. The model output may convincingly inform local stakeholders and regional decision makers who consider spatial variation in SOC sequestration in this landscape.

Acknowledgments This study is financially supported by the National Natural Science Foundation of China (Nos. 41230745, 41201182), the Chinese Academy of Sciences (Nos. XDA05050602-05-01 and GJHZ1215), and the Academy of Finland (No. 256231). We thank the three anonymous reviewers for their constructive comments and suggestions.

\section{References}

Adamopoulos S, Voulgaridis E, Passialis C (2005) Variation of certain chemical properties within the stemwood of black locust (Robinia pseudoacacia L.). Eur J Wood Prod 63:327-333

Chang RY, Fu BJ, Liu GH, Wang S, Yao XL (2012) The effects of afforestation on soil organic and inorganic carbon: a case study of the Loess Plateau of China. Catena 95:145-152

Cheng JM, Cheng J, Yang XM (2011) Grassland vegetation and soil carbon sequestration in the Loess Plateau. J Nat Resour 26(3):401-411 
Conant RT, Smith GR, Paustian K (2003) Spatial variability of soil carbon in forested and cultivated sites: implications for change detection. J Environ Qual 32:278-286

Dang Y, Ren W, Tao B, Chen G, Lu C, Yang J, Pan S, Wang G, Li S, Tian H (2014) Climate and land use controls on soil organic carbon in the Loess Plateau region of China. PLoS One 9(5):e95548. doi:10.1371/journal.pone.0095548

Deng L, Liu GB, Shangguan ZP (2014) Land use conversion and changing soil carbon stocks in China's grain-for-green' program: a synthesis. Glob Change Biol 20(11):3544-3556. doi:10.1111/gcb.12508

Falloon P, Smith P, Bradley RI, Milne R, Tomlinson RW, Viner D, Livermore M, Brown TAW (2006) RothCUK-a dynamic modelling system for estimating changes in soil C from mineral soils at $1-\mathrm{km}$ resolution in the UK. Soil Use Manage 22:274-288

Fang JY, Guo ZD, HU HF, Kato T, Muraoka H, Son Y (2014) Forest biomass carbon sinks in East Asia, with special reference to the relative contributions of forest expansion and forest growth. Global Change Biol. doi:10.1111/gcb.12512

Feng X, Fu B, Yang X, Lv Y (2010) Remote sensing of ecosystem services: an opportunity for spatially explicit assessment. Chin Geogr Sci 20(6):522-535

Feng X, Fu B, Lu N, Zeng Y, Wu B (2013) How ecological restoration alters ecosystem services: an analysis of carbon sequestration in China's Loess Plateau. Sci Rep 2846. doi:10.1038/srep02846

Gong J, Chen LD, Fu BJ, Huang Y, Huang Z, Peng H (2006) Effects of land use on soil nutrients in the loess hilly area of the Loess Plateau, China. Land Degrad Dev 17:453-465

Grunwald S, Vasques GM (2010) Synthesis of knowledge on soil carbon spatial patterns across a large subtropical soillandscape in Southern U.S. 19th world congress of soil science, soil solutions for a changing world. 1-6 August 2010, Brisbane, Australia

Hashimoto S, Wattenbach M, Smith P (2011) Litter carbon inputs to the mineral soil of Japanese Brown forest soils: comparing estimates from the RothC model with estimates from MODIS. J For Res 16:16-25. doi:10.1007/s10310010-0209-6

Jandl R, Lindner M, Vesterdal L, Bauwens B, Baritz R, Hagedorn F, Johnson DW, Minkkinen K, Byrne KA (2007) How strongly can forest management influence soil carbon sequestration? Geoderma 137:253-268

Jastrow JD, Miller RM, Matamala R (2005) Elevated atmospheric carbon dioxide increases soil carbon. Global Change Biol 11:2057-2064

Jensen LS, Salo Y, Palmason F, Breland TA, Henriksen TM, Stenberg B, Pedersen A, Lundstro C, Esala M (2005) Influence of biochemical quality on $\mathrm{C}$ and $\mathrm{N}$ mineralisation from a broad variety of plant materials in soil. Plant Soil 273:307-326

Jobbágy E, Jackson R (2000) The vertical distribution of soil organic carbon and its relation to climate and vegetation. Ecol Appl 10:423-436

Lal R (2004) Soil carbon sequestration to mitigate climate change. Geoderma 123:1-22

Lauenroth WK (2000) Methods of estimating belowground net primary production. In: Sala OE, Jackson RB, Mooney HA et al (eds) Methods in ecosystem science. Springer, New York, pp 58-71
Li LB, Tu CL, Zhao ZQ, Cui LF, Liu WJ (2011) Distribution characteristics of soil organic carbon and its isotopic composition for soil profiles of Loess Plateau under different vegetation conditions. Earth Environ 39(4):441-448

Liu W, Cheng JM, Chen FR, Gao Y (2010) Characteristic of organic carbon density and organic carbon storage in the natural grassland of center Loess Plateau. Acta Agrestia Sin 19(3):425-431

Liu YC, Wang QF, Yu GR, Zhu XJ, Zhan XY, Guo Q, Yang H, Li SG, Hu ZM (2011a) Ecosystems carbon storage and carbon sequestration potential of two main tree species for the grain for green project on China's hilly Loess Plateau. Acta Ecol Sin 31(15):4277-4286

Liu ZP, Shao MA, Wang YQ (2011b) Effect of environmental factors on regional soil organic carbon stocks across the Loess Plateau region, China. Agric Ecosyst Environ 142:184-194

Liu ZP, Shao MA, Wang YQ (2012) Large-scale spatial variability and distribution of soil organic carbon across the entire Loess Plateau, China. Soil Res 50:114-124

Lu N, Liski J, Chang RY, Akujärvi A, Wu X, Jin TT, Wang YF, Fu BJ (2013) Soil organic carbon dynamics of black locust plantations in the middle Loess Plateau area of China. Biogeosciences 10:7053-7063

Luo ZK, Wang EL, Bryan BA, King D, Zhao G, Pan XB, BendeMichl U (2013) Meta-modeling soil organic carbon sequestration potential and its application at regional scale. Ecol Appl 23(2):408-420

Meersmans J, De Ridder F, Canters F, De Baets S, Van Molle M (2009) A multiple regression approach to assess the spatial distribution of soil organic carbon (SOC) at the regional scale (Flanders, Belgium). Geoderma 152:43-52

Mueller TG, Pierce FJ (2003) Soil carbon maps: enhancing spatial estimates with simple terrain attributes at multiple scales. Soil Sci Soc Am J 67:258-267

Ogle SM, Breidt FJ, Easter M, Williams S, Killian K, Paustian K (2010) Scale and uncertainty in modeled soil organic carbon stock changes for US croplands using a process-based model. Global Change Biol 16:810-822

Piao S, Fang J, He J (2006) Variations in vegetation net primary production in the Qinghai-Xizang Plateau, China, from 1982 to 1999. Clim Change 74:253-267. doi:10.1007/ s10584-005-6339-8

Pickett STA, Cadenasso ML (1995) Landscape ecology: spatial heterogeneity in ecological systems. Science 269:331-334

Poeplau C, Don A (2013) Sensitivity of soil organic carbon stocks and fractions to different land-use changes across Europe. Geoderma 192:189-201

Poeplau C, Don A, Vesterdal L, Leifeld J, Van Wesemael B, Schumacher J, Gensior A (2011) Temporal dynamics of soil organic carbon after land-use change in the temperate zone- carbon response functions as a model approach. Glob Change Bio 17:2415-2427. doi:10.1111/j.1365-2486. 2011.02408.x

Post WM, Kwon KC (2000) Soil carbon sequestration and landuse change: processes and potential. Global Change Biol 6:317-328

Potter CS, Randerson JT, Field CB, Matson PA, Vitousek PM, Mooney HA, Klooster SA (1993) Terrestrial ecosystem production: a process model based on global satellite and surface data. Global Biogeochem Cy 7:811-841 
Schulp CJE, Verburg PH (2009) Effect of land use history and site factors on spatial variation of soil organic carbon across a physiographic region. Agric Ecosyst Environ 133:86-97

Schulp CJE, Nabuurs GN, Verburg PH (2008) Future carbon sequestration in Europe-effects of land use change. Agric Ecosyst Environ 127:251-264

Shi H, Wen Z, Paull D (2013a) Estimation of carbon carrying capacity in the Yanhe River catchment of China's Loess Plateau. Acta Agric Scand Sect B Soil Plant Sci 63(6):543-553. doi:10.1080/09064710.2013.820786

Shi SW, Zhang W, Zhang P, Yu YQ, Ding F (2013b) A synthesis of change in deep soil organic carbon stores with afforestation of agricultural soils. For Ecol Manage 296:53-63

Sievänen R, Salminen O, Lehtonen A, Ojanen P, Liski J, Ruosteenoja K, Tuomi M (2014) Carbon stock changes of forest land in Finland under different levels of wood use and climate change. Ann For Sci 71:255-265. doi:10.1007/ s13595-013-0295-7

Song XZ, Peng CH, Zhou GM, Jiang H, Wang WF (2014) Chinese grain for green program led to highly increased soil organic carbon levels: a meta-analysis. Sci Rep 4:4460. doi:10.1038/srep04460

Thum T, Räisänen P, Sevanto S, Tuomi M, Reick C, Vesala T, Raddatz T, Aalto T, Järvinen H, Altimir N, Pilegaard K, Zoltan N, Rambal S, Liski J (2011) Soil carbon model alternatives for ECHAM5/JSBACH climate model: evaluation and impacts on global carbon cycle estimates. J Geophys Res 116:G02028. doi:10.1029/2010JG001612

Todd-Brown KEO, Randerson JT, Hopkins F, Arora V, Hajima T, Jones C, Shevliakova E, Tjiputra J, Volodin E, Wu T, Zhang Q, Allison SD (2014) Changes in soil organic carbon storage predicted by earth system models during the 21st century. Biogeosciences 11:2341-2356

Tuomi M, Vanhala P, Karhu K, Fritze H, Liski J (2008) Heterotrophic soil respiration-comparison of different models describing its temperature dependence. Ecol Model 211(1-2):182-190

Tuomi M, Thum T, Jarvinen H, Fronzek S, Berg B, Harmon M, Trofymow JA, Sevanto S, Liski J (2009) Leaf litter decomposition-estimates of global variability based on Yasso07 model. Ecol Model 220(23):3362-3371

Tuomi M, Laiho R, Repo A, Liski J (2011a) Wood decomposition model for boreal forests. Ecol Model 222(3):709-718

Tuomi M, Rasinmaki J, Repo A, Vanhala P, Liski J (2011b) Soil carbon model Yasso07 graphical user interface. Environ Model Softw 26(11):1358-1362

Upadhyay TP, Solberg B, Sankhayan PL, Shahi C (2013) Landuse changes, forest/soil conditions and carbon sequestration dynamics: a bio-economic model at watershed level in Nepal. J Bioecon 15:135-170

Vagen TG, Winowiecki LA (2013) Mapping of soil organic carbon stocks for spatially explicit assessments of climate change mitigation potential. Environ Res Lett 8:015011

Wang HQ, Cornell JD, Hall CAS, Marley DP (2002) Spatial and seasonal dynamics of surface soil carbon in the Luquillo experimental forest, Puerto Rico. Ecol Model 147:105-122
Wang CY, Zhou JB, Wang X, Xia ZM (2011a) Contents and biodegradation of soluble organic carbon in different plant residues from the Loess Plateau. Environ Sci 32:1139-1145

Wang W, Dungan J, Hashimoto H, Michaelis A, Milesi C, Ichii K, Nemani R (2011b) Diagnosing and assessing uncertainties of terrestrial ecosystem models in multimodel ensemble experiment: 1. Primary production. Global Change Biol 17:1350-1366. doi:10.1111/j.1365-2486. 2010.02309.x

Wang Z, Liu GB, Xu MX, Zhang J, Wang Y, Tang L (2012) Temporal and spatial variations in soil organic carbon sequestration following revegetation in the hilly Loess Plateau, China. Catena 99:26-33

Wiesmeier M, Prietzel J, Barthold F, Spörlein P, Geu U, Hangen E, Reischl A, Schilling B, von Lützow M, Kögel-Knabner I (2013) Storage and drivers of organic carbon in forest soils of southeast Germany (Bavaria)—implications for carbon sequestration. For Ecol Manage 295:162-172

Wu X, Lu N, Liski J, Akujärvi A, Liu GH, Wang YF, Li F, Zeng Y, Fu BJ (2014) Dynamics of soil organic carbon stock at the catchment scale in the Loess Plateau-Comparison of model simulation with measurements. Landscape Ecol. doi:10.1007/s10980-014-0110-3

Xu GC, Li ZB, Li P, Lu KX, Wang Y (2013) Spatial variability of soil organic carbon in a typical watershed in the source area of the middle Dan River, China. Soil Res 51:41-49

Yadav V, Malanson G (2008) Spatially explicit historical land use land cover and soil organic carbon transformations in Southern Illinois. Agric Ecosyst Environ 123:280-292

Yang S (2010) The evaluation of carbon in farmland in Yanhe River Catchment in Loess Hilly and Gully Region. Thesis of Northwest A \& F University, China

Yang YH, Monhammat A, Feng JM, Zhou R, Fang JY (2007) Storage, patterns and environmental controls of soil organic carbon in China. Biogeochemistry 84:131-141

Yang XM, Cheng JM, Meng L, Han JJ, Fan WJ (2010) Analysis on soil organic carbon and nutrients storages in different forests in Ziwuling. Res Soil Water Conserv 17(3):130-134

Zhang N, Liang YM (2002) Studies on the below-ground/aboveground biomass ratio of natural grassland in loess hilly region. Acta Pratacult Sin 11(2):72-78

Zhang XB, Shangguan ZP (2005) The bio-cycle patterns of nutrient elements and stand biomass in forest communities in hilly loess regions. Acta Ecol Sin 25(3):527-537

Zhang C, Liu GB, Xue S, Sun C (2013) Soil organic carbon and total nitrogen storage as affected by land use in a small watershed of the Loess Plateau, China. Eur J Soil Biol 54:16-24

Zhang K, Dang H, Tan S, Cheng X, Zhang Q (2010) Change in soil organic carbon following the 'grain-for-green' programme in China. Land Degrad Dev 21:16-28

Zhao SW, Lu L, Liu NN, Wu JS, Su J, Yang YH (2006) Effects of ecosystem conversion on the characteristics of soil organic carbon in Ziwuling forest region. Acta Bot Boreal Occident Sin 26(5):1030-1035 